\title{
UPAYA PENGEMBANGAN AGRIBISNIS TERNAK DOMBA MELALUI PERBAIKAN MUTU PAKAN DAN PENINGKATAN PERAN KELOMPOKTANI DI KECAMATAN PANUMBANGAN KABUPATEN CIAMIS
}

\author{
Oleh \\ TITA RAHAYU
}

Fakultas Pertanian Universitas Galuh Ciamis e-mail: titarahayu1985@gmail.com

\begin{abstract}
Abstrak
Upaya Pengembangan Agribisnis Ternak Domba Melalui Perbaikan Mutu Pakan dan Peningkatan Peran Kelompoktani di Kecamatan Panumbangan Kabupaten Ciamis dengan mengambil lokasi Kelompoktani Mekar 1 Desa Golat. Tujuannya untuk meningkatkan pengetahuan dan keterampilan petani dalam pengembangan agribisnis ternak domba melalui perbaikan mutu pakan, meningkatkan peran dan fungsi kelompoktani secara optimal. Untuk meningkatkan pengetahuan petani dalam pemilihan pakan yang memenuhi syarat kualitas dan kuantitas pakan yang baik, meningkatkan pertambahan berat badan harian ternak domba serta meningkatkan pendapatan petani. Penyuluhan yang dilakukan secara individual maupun kelompok. Metode yang digunakan adalah pertemuan kelompok, ceramah, diskusi, anjangsana dan demostrasi cara. Materi yang disampaikan meliputi subsistem agro input dan agroproduksi diantaranya dalam aspek pemilihan bibit, perbaikan mutu pakan, perkandangan, perawatan ternak, pencegahan, pengobatan penyakit, pengelolaan reproduksi dan subsistem pemasaran hasil. Pembinaan dilakukan pada 20 orang peternak sebagai sampel. Kaji terap teknologi dilaksanakan pada 8 ekor ternak domba dengan kisaran umur 6-8 bulan yang dibagi menjadi 2 perlakuan. Kelompok pertama (Po) diberi rumput saja (Kebiasaan petani), kelompok kedua (P1) diberi rumput $10 \%$ dari berat badan ditambah 200 gr dedak padi dan Bioplus 300 gr per ekor (Satu dosis pemberian).
\end{abstract}

Kata kunci: perbaikan mutu pakan, peningkatan peran kelompok tani dan kaji terap teknologi

\section{PENDAHULUAN}

Proyeksi jumlah penduduk dunia pada tahun 2025 diperkirakan akan meningkat mencapai 8,5 miliar orang atau lebih. Untuk memenuhi kebutuhan pangan dan gizi bagi masyarakat, khususnya kebutuhan protein hewani yang bersumber dari daging, maka subsistem peternakan sebagai salah satu bagian dari pembangunan pertanian harus dikembangkan (Cahyono, 1998).

Pengembangan agribisnis merupakan salah suatu usaha agar seluruh sistem yang terlibat dalam agribisnis dapat bergerak saling mendukung. Dalam usaha menggerakkan semua subsistem agribisnis ternak domba akan melibatkan banyak pihak. Sehingga tidak bias dilakukan dalam waktu yang singkat, hal ini karena sistem yang telah lama berjalan kurang memenuhi syarat, maka usaha untuk menggerakkan subsistem agar berjalan sebagaimana mestinya memerlukan waktu yang lama. (Saragih, 2001).

Dalam rangka mengembangkan agribisnis ternak domba melalui perbaikan mutu pakan di Kecamatan Panumbangan, perlu dilaksanakan pembinaan bagi peternak dalam aspek manajemen usaha tani khususnya dalam perbaikan mutup akan. Untuk pengembangannya perlu adanya dorongan dan motivasi yang tinggi, agar pembinaan kepada petani dan kelompok tani menjadi lebih efektif.

Kegiatan yang dilakukan dalam pembinaan usaha tani di Kecamatan Panumbangan meliputi kegiatan penyuluhan teknik budidaya ternak domba dan pemasaran, karena hal-hal tersebut merupakan kegiatan yang saling berkaitan dalam pengembangan agribisnis ternak domba dan peningkatan peran kelompoktani.

Kegiatan penyuluhan dalam upaya peningkatan mutu pakan meliputi penggunaan teknologi pakan berupa Probiotik Bioplus di Kelompoktani Mekar 1 merupakan salah satu pengenalan teknologi pakan dalam meningkatkan berat badan ternak domba.

$$
\text { Berdasarkan hasil survai yang }
$$

dilakukan di Kecamatan Panumbangan, permasalahan yang dihadapi dalam Upaya Pengembangan Agribinis Ternak Domba Melalui Perbaikan Mutu Pakan dan Peningkatan Peran Kelompoktani adalah 


\section{AIMBAR \\ Agribisnis}

ISSN 2460-4321

Volume 1・ Nomor 2・ Januari 2016

rendahnya pengetahuan dan keterampilan petani dalam penerapan saptausaha karena penerapan teknologi budidaya peternakan masih rendah khususnya pada aspek pakan, rendahnya produktivitas domba dan kelompoktani di Kecamatan Panumbangan belum berfungsi sebagaimana mestinya. Tujuan yang diharapkan dari penelitian ini yaitu meningkatkan peran dan fungsi kelompoktani secara optimal, meningkatkan pertambahan berat badan harian ternak domba dan meningkatkan pendapatan petani. Manfaat yang diharapkan dari penelitian ini yaitu dapat meningkatkan pengetahuan dan keterampilan petani dalam menerapkan sapta usaha, dapa tmendorong petani untuk beragribisnis lebih efektif dan efisien serta dapat menggerakan peran kelompok tani menjadi lebih mandiri dan dinamis.

\section{TINJAUAN PUSTAKA}

UU No 16 Tahun 2006, menyatakan bahwa penyuluhan pertanian adalah proses pembelajaran bagi para pelaku utama serta para pelaku usaha agar mereka mau dan mampu menolong dan mengorganisasikan dirinya dalam mengakses informasi pasar, teknologi, permodalan dan sumberdaya lainnya, sebagai upaya untuk meningkatkan produktivitas, efisiensi usaha, pendapatan dan kesejahteraannya serta meningkatkan kesadaran dalam pelestarian fungsi lingkungan hidup.

Tujuan utama dari penyuluhan adalah mempengaruhi para petani dan keluarganya agar berubah perilaku sesuai yang diinginkan (Oleh pihak penyuluh) yang akan menyebabkan perbaikan mutu hidup daripada keluarga tani dengan demikian penyuluhan yang efektif adalah yang dapat menimbulkan perubahan informasi pada diri individu-individu petani atau memberiinformasi baru kepada mereka, memperbaiki kemampuannya dalam kebiasaankebiasaan baru serta menumbuhkan perasaan tertentu terhadap sesuatu yang dikehendaki (Slamet, 2003).

Kelembagaan penyuluh pertanian adalah sebagai unit pengelolaan dan penyelenggara penyuluhan pertanian, baik yang berstatus Badan/Kantor/Balai/UPTD penyuluhan pertanian maupun yang berstatus Sub Dinas yang dibentuk berdasarkan peraturan yang telah ditetapkan oleh Surat Keputusan Menteri
(Badan Pengembangan Sumberdaya Manusia Pertanian, 2005).

Menurut Purwanto (2005), fungsi kelompoktani nelayan sebagai unit produksi dengan cara peningkatan produksi dan produktivitas, pencapaian skala usaha ekonomis, sebagai kelas belajar mengajar dengan cara petani belajar antar petani dan pemberdaya petani, sebagai wahana kerjasama dengan cara efektivitas program, efisiensi usaha serta berakses ke instansi pendukung.

Pembinaan kelompoktani adalah setiap upaya yang dilakukan untuk meningkatkan dan mengembangkan kemampuan kelompoktani dalam melaksanakan kegiatan sesuai dengan peranannya (Marzuki, 2001).

Metode penyuluhan pertanian merupakan cara-cara penyampaian materi penyuluhan secara sistematis hingga materi penyuluhan dapat dimengerti dan diterima petani sasaran (Ibrahim et all, 2003).

Kaji terap merupakan suatu metoda penyuluhan pertanian untuk meningkatkan kemampuan petani-nelayan dan memilih paket teknologi usahatani dari beberapa alternatif yang telah direkomendasikan sebelum di demonstrasikan dan dianjurkan yang pelaksanaannya dilakukan oleh kontak tani nelayan di lahan usahataninya dengan bimbingan penyuluh pertanian (Departemen Pertanian, 2003).

Agribisnis peternakan merupakan sebuah sistem pengelolaan ternak secara terpadu dan meyeluruh yang meliputi semua kegiatan mulai dari pembuatan dan penyaluran sarana produksi ternak, kegiatan usaha produksi (budidaya), penyimpanan dan pengolahan serta penyaluran dan pemasaran produk peternakan yang di dukung oleh lembaga penunjang seperti perbankan dan kebijakan pemerintah (Rahardidan R. Hartono, 2003).

Selain hijauan dan konsentrat ternak dapat diberi pakan tambahan atau pakan pelengkap guna meningkatkan daya cerna pakan. Domba juga memiliki kebutuhan akan berbagai vitamin dan mineral, yang sebenarnya bias tercukupi dengan pemberian bahan pakan yang bervariasi (Sodiq dan Zainal Abidin, 2002).

Bioplus diperoleh dalam isi rumen dalam bentuk kering. Isi rumen sebagai pakan tambahan merupakan penghasil mikroba pemecah serat kasar yang tinggi sekali 
kemampuannya, bioplus dikembangkan dari limbah rumah potong hewan. Isi rumen yang ditampung kemudian diseleksi dan dipelihara (Difermentasi) dengan diberi pakan jerami. Untuk mempermudah pemberian maka bahan tersebut dikeringkan dengan pemanasan stabil. Setelah kering pakan digiling dan diayak sehingga berbentuk serbuk halus. Produk pakan tambahan dalam bentuk serbuk kering inilah yang disebut Bioplus (Sarwono dan Arianto, 2002).

\section{METODE PENELITIAN}

Penelitian ini di laksanakan di Kecamatan Panumbangan Kabupaten Ciamis, dengan mengambil lokasi Kelompoktani Mekar 1 Desa Golat. Sebelum penelitian, dilakukan survai untuk mengidentifikasi kelompoktani dan kondisi agribisnis sebagai dasar pelaksanaan kegiatan tersebut.

Penyuluhan dilakukan dengan menggunakan pendekatan kelompok dan individu. Pendekatan kelompok dilakukan melalui pertemuan antar anggota kelompoktani Mekar 1 Desa Golat. Pendekatan indiviu dilakukan dalam kegiatan anjangsana, metode yang digunakan adalah ceramah, diskusi dan demonstrasi cara. Kegiatan penyuluhan tersebut bertujuan untuk merubah pengetahuan, keterampilan dan sikap petani agar mereka dapat berusaha tani dengan baik dan berorientasi agribisnis sehingga dapat meningkatkan pendapatan serta kesejahteraannya. Media penyuluhan yang digunakan berupa brosur dan leaflet.

Biasanya peternak di Kecamatan Panumbangan dalam pemberian pakan berupa rumput dan daun-daunan, sedangkan untuk pakan tambahan, pakan penguat dan pakan suplemen tidak diberikan. Oleh karena itu pembinaan dilakukan pada aspek pakan yang memenuhi syarat kualitas dan kuantitas. Penyuluhan tentang cara pembuatan pakan tambahan seperti bioplus dilaksanakan secara demonstrasi cara, hal ini bertujuan agar peternak mengetahui bahan-bahan dan cara pembuatannya sehingga peternak bias melakukannya sendiri. Sasarannya adalah anggota kelompoktani, pemuda tani dan keluarga tani.

Subsistem pemasaran merupakan salah satu kunci keberhasilan untuk meningkatkan pendapatan peternak. Peternak di Kecamatan
Panumbangan umumnya menjual ternaknya ke pasar hewan atau konsumen, dimana cara penjualannya dengan cara berkelompok. Pemasaran dan penentuan harga ternak domba dilakukan antara peternak dan pedagang dengan melihat tampilan fisik dari ternak. Dalam penentuan harga jual ternak sering dirugikan oleh tengkulak. Untuk mengatasi hal tersebut, peternak diberi penyuluhan tentang pentingnya informasi pasar, memperpendek rantai pemasaran dan melakukan penimbangan berat badan domba sebelum dijual.

Kegiatan kaji terap dimaksudkan untuk memberikan alternatif rekomendasi sekaligus meyakinkan peternak. Kaji terap berfungsi sebagai kegiatan demonstrasi plot, karena membuktikan hasil dan cara yang dapat dilakukan langsung oleh peternak. Tujuan yang ingin dicapai adalah peningkatan bobot badan domba akibat penggunaan Bioplus. Dengan meningkatnya pertambahan bobot badan domba diharapkan pendapatan peternak meningkat, analisis yang akan digunakan untuk mengetahui perbedaan yang muncul pada penelitian ini adalah dengan menggunakan uji t.

Alat dan bahan yang digunakan adalah domba 8 ekor, bioplus, dedak padi dan kandang serta timbangan. Penelitian dialokasikan dalam dua perlakuan yaitu PO dan P1. Masingmasing perlakuan menggunakan 4 ekor domba jantan dengan umur berkisar antara 6-8 bulan. Kelompok utama (Po) diberi rumput saja (Kebiasaan petani), kelompok kedua (P1) diberi rumput $10 \%$ dari berat badan ditambah $200 \mathrm{gr}$ dedak padi dan Bioplus 300 gr per ekor (Satu dosis pemberian). Sebelum diberi perlakuan terlebih dahulu dilakukan penimbangan, dimana untuk mengetahui berat badan awal dan pemberian obat vaving Vern-O per ekor, pada akhir perlakuan dilakukan penimbangan untuk mengetahui keadaan berat badan akibat perlakuan. Selama perlakuan domba diberi air minum secara teratur.

\section{HASIL DAN PEMBAHASAN}

Hasil pembinaan yang dilakukan selama penelitian dalam pemberdayaan kelompoktani meliputi timbulnya kemandirian petani, terciptanya kerjasama antara anggota dalam menunjang kegiatan usaha serta mampu menampung aspirasi anggota dalam melakukan usaha. Penyuluhan mengenai kelompoktani berpengaruh nyata karena menggunakan 


\section{AIMBAR Agribisnis \\ ISSN 2460-4321}

Volume $1 \cdot$ Nomor $2 \cdot$ Januari 2016

metode penyuluhan yang sesuai (anjangsana, ceramah, diskusi) sehingga mempengaruhi tingkat adopsi dari petani/kelompoktani sasaran penyuluhan, sehingga tujuan penyuluhan dapat tercapai, tingkat adopsi dari petani/kelompoktani berupa kesadaran dan minat.
Kaji terap dimaksudkan sebagai pembanding dan diharapkan sebagai dasar pemikiran bagi peternak dalam memilih paket teknologi yang lebih menguntungkan. Hasil penimbangan ternak domba kaji terap dapat dilihat pada Tabel 1 .

Tabel 1. Hasil Penimbangan 49 Hari Pelaksanaan Kaji Terap

\begin{tabular}{|c|c|c|c|c|c|c|c|c|c|}
\hline \multirow{2}{*}{ Perlakuan } & \multirow{2}{*}{ Ulangan } & \multirow{2}{*}{ Awal } & \multicolumn{7}{|c|}{ Hasil Penimbangan } \\
\hline & & & 1 & 2 & 3 & 4 & 5 & 6 & 7 \\
\hline \multirow{6}{*}{$\mathrm{PO}$} & U1 & 20 & 20.5 & 21 & 21.5 & 22 & 22.5 & 23 & 24 \\
\hline & $\mathrm{U} 2$ & 22 & 22.5 & 23 & 23.5 & 24 & 24.5 & 25 & 26 \\
\hline & $\mathrm{U} 3$ & 21 & 22 & 22.5 & 23 & 23.5 & 24 & 24.5 & 25 \\
\hline & $\mathrm{U} 4$ & 20 & 21.5 & 22 & 22.5 & 23 & 23.5 & 24 & 25 \\
\hline & Jumlah & 83 & 86.5 & 88.5 & 90.5 & 92.5 & 94.5 & 96.5 & 100 \\
\hline & Rata-Rata & 20.75 & 21.6 & 22.1 & 22.6 & 23.1 & 23.6 & 24.1 & 25 \\
\hline \multirow{2}{*}{ Perlakuan } & \multirow{2}{*}{ Ulangan } & \multirow{2}{*}{ Awal } & \multicolumn{7}{|c|}{ Hasil Penimbangan } \\
\hline & & & 1 & 2 & 3 & 4 & 5 & 6 & 7 \\
\hline \multirow{6}{*}{$\mathrm{P} 1$} & U1 & 21 & 22 & 23 & 23.5 & 25 & 25.5 & 26 & 26.5 \\
\hline & $\mathrm{U} 2$ & 22 & 23.5 & 24 & 25 & 25.5 & 26 & 27 & 28 \\
\hline & U3 & 20 & 21 & 23 & 23.5 & 25 & 26 & 27 & 27.5 \\
\hline & $\mathrm{U} 4$ & 21 & 21.5 & 23 & 23.5 & 25 & 26 & 26.5 & 28 \\
\hline & Jumlah & 84 & 88 & 93 & 95.5 & 100.5 & 103.5 & 106.5 & 110 \\
\hline & Rata-Rata & 21 & 22 & 23.25 & 23.8 & 25.1 & 25.8 & 26.6 & 27.5 \\
\hline
\end{tabular}

Tabel 2. Pertambahan Berat Badan Pada Ulangan

\begin{tabular}{|c|c|c|c|c|c|}
\hline \multirow{2}{*}{ Perlakuan } & \multirow{2}{*}{ Ulangan } & \multicolumn{3}{|c|}{ Kg } & \multirow{2}{*}{ ADG } \\
\hline & & X1 & $\mathrm{X} 2$ & (X1-X2) & \\
\hline \multirow{6}{*}{$\mathrm{PO}$} & U1 & 20 & 24 & 4 & 81.6 \\
\hline & U2 & 22 & 26 & 4 & 81.6 \\
\hline & U3 & 21 & 25 & 4 & 81.6 \\
\hline & $\mathrm{U} 4$ & 20 & 25 & 5 & 102 \\
\hline & Jumlah & 83 & 100 & 17 & 346.8 \\
\hline & Rata-rata & 20.75 & 25 & 4.25 & 86.7 \\
\hline \multirow{2}{*}{ Perlakuan } & \multirow{2}{*}{ Ulangan } & & $\mathrm{Kg}$ & & \multirow{2}{*}{ ADG } \\
\hline & & X1 & $\mathbf{X 2}$ & $(\mathrm{X} 1-\mathrm{X} 2)$ & \\
\hline \multirow{6}{*}{$\mathrm{P} 1$} & U1 & 21 & 26.5 & 5.5 & 112.24 \\
\hline & U2 & 22 & 28 & 6 & 122.45 \\
\hline & U3 & 20 & 27.5 & 7.5 & 153.06 \\
\hline & $\mathrm{U} 4$ & 21 & 28 & 7 & 142.85 \\
\hline & Jumlah & 84 & 110 & 26 & 530.6 \\
\hline & Rata-rata & 21 & 27.5 & 6.5 & 132.65 \\
\hline
\end{tabular}

Tabel 3. Data Pengaruh Pemberian Pelengkap Bioplus Terhadap Pertambahan Berat Badan Domba (gram/ekor/hari)

\begin{tabular}{|c|c|c|c|c|c|c|}
\hline \multirow{2}{*}{ Perlakuan } & \multicolumn{4}{|c|}{ Ulangan } & \multirow{2}{*}{ Jumlah } & \multirow{2}{*}{ Rata-rata } \\
\hline & U1 & U2 & U3 & U4 & & \\
\hline PO & 81.6 & 81.6 & 81.6 & 102 & 346.8 & 86.7 \\
\hline P1 & 112.24 & 122.45 & 153.06 & 142.85 & 530.6 & 132.65 \\
\hline
\end{tabular}


Dari data tersebut menunjukkan perbedaan pertambahan berat badan harian domba pada setiap perlakuan. Hal tersebut disebabkan jumlah mikroba menguntungkan yang berfungsi untuk mencerna serat kasar sebagai akibat dari pemberian Bioplus.

$$
\begin{aligned}
& \frac{\left(\sum \mathrm{PO}\right)^{2}}{\mathrm{n}}=\frac{(346,8)^{2}}{4}=30067 \\
& \mathrm{~S}^{2} \mathrm{PO}=\frac{\sum(\mathrm{PO})^{2}-\left(\sum \mathrm{PO}^{2}\right) / \mathrm{n}}{\mathrm{n}-1} \\
& =\frac{81,62^{2}+81,62^{2}+81,62^{2}+102^{2}-(346,8)^{2} / 4}{4-1} \\
& =\frac{6658,6+6658,6+6658,6+10404-(30067)}{3} \\
& =\frac{312,8}{3}=104,3 \\
& \frac{\left(\sum \mathrm{P} 1\right)^{2}}{\mathrm{n}}=\frac{(530,6)^{2}}{4}=70384 \\
& \mathrm{~S}^{2} \mathrm{P} 1=\frac{\sum(\mathrm{PO})^{2}-\left(\sum \mathrm{PO}^{2}\right) / \mathrm{n}}{\mathrm{n}-1} \\
& =\frac{112,24^{2}+122,45^{2}+153,06^{2}+142,85^{2}-(70384)}{4-1} \\
& =3386,1 \\
& \mathrm{SD} \quad=\frac{\sqrt{\mathrm{S}^{2} \mathrm{PO}}}{\mathrm{n}}+\frac{\sqrt{\mathrm{S}^{2} \mathrm{P} 1}}{\mathrm{n}} \\
& =\frac{\sqrt{104,3}}{4}+\frac{\sqrt{3386,1}}{4} \\
& =\sqrt{26,07+846,5} \\
& =\sqrt{872,6}=29,54 \\
& \text { thitung }=\frac{X_{1}-X_{2}}{\sqrt{\frac{1}{n}+\frac{1}{n}}} \\
& \text { thitung }=\frac{86,7-132,65}{\sqrt{\frac{1}{4}+\frac{1}{4}}} \\
& \text { thitung }=\frac{-44,95}{(29,54)(0,7)}=\frac{-44,95}{20,68} \\
& =-2,174 \ldots \ldots 2,174 \\
& \mathrm{t} \text { tabel }=t_{0,05}=1,94
\end{aligned}
$$




\section{AIMBAR \\ Agribisnis}

ISSN 2460-4321

Volume $1 \cdot$ Nomor $2 \cdot$ Januari 2016

Hipotesa : Karena t hitung (2.174) t tabel (1.94) maka HO ditolak H1 diterima. Artinya terdapat perbedaan yang sangat nyata dari kedua perlakuan dalam pemberian pakan tambahan yaitu Bioplus.

Berdasarkan perhitungan analisa usaha yang telah dilakukan dapat diketahui bahwa pendapatan petani sebelum pembinaan adalah Rp. 44.875,00 dengan R/C Ratio sebesar 1.01 sedangkan setelah dilakukan pembinaan dapat meningkat menjadi Rp. 300.875,00 dengan R/C Ratio 1.08. Dari hasil peningkatan yang telah diperoleh dapat dikemukakan bahwa pakan tambahan berupa Bioplus layak direkomendasikan kepada petani. Untuk lebih jelasnya dapat dilihat pada Tabel 4.

Tabel 4 Analisa Usaha Agribisnis Ternak Domba Untuk 8 Ekor dengan Lama Pemeliharaan 90 Hari

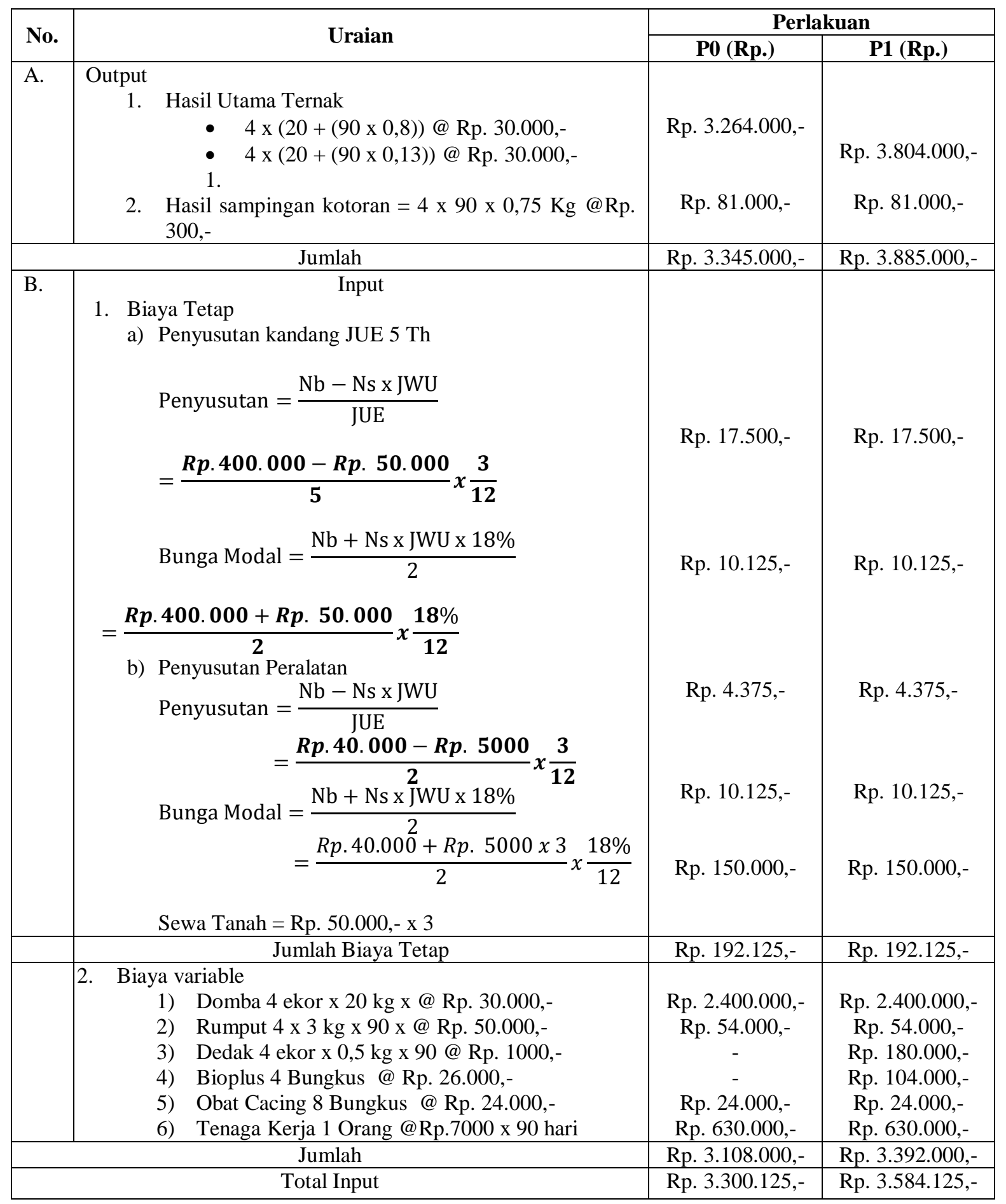


Lanjutan Tabel 4

\begin{tabular}{|c|c|c|c|}
\hline C. & $\begin{array}{l}\text { Pendapatan } \\
\text { 1) Pendapatan Pengelola = A - B } \\
\text { 2) Pendapatan Keluarga (Pendapatan Pengelola + Sewa } \\
\text { Tanah Milik Sendiri + Tenaga Kerja + Biaya Rumput })\end{array}$ & $\begin{array}{l}\text { Rp. } 44.875,- \\
\text { Rp. } 878.875,-\end{array}$ & $\begin{array}{l}\text { Rp. } 300.875,- \\
\text { Rp. } 1.134 .875,-\end{array}$ \\
\hline D. & 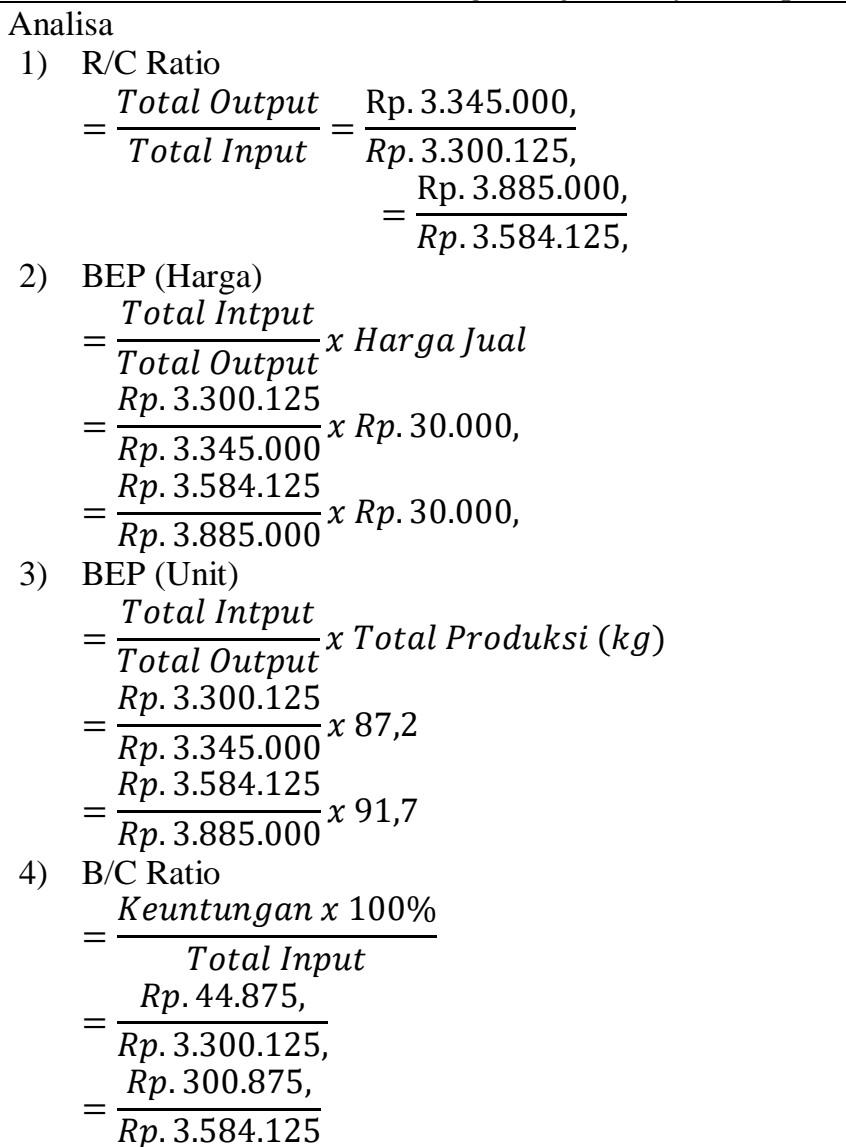 & 29.400 & 27.600 \\
\hline
\end{tabular}

\section{PENUTUP}

Meningkatnya peran serta anggota kelompoktani dengan pihak lain dalam pengembangan agribisnis ternak domba ditunjukkan dengan adanya peningkatan pengetahuan dalam peningkatan peran kelompoktani sehingga dikategorikan cukup berhasil. Kaji terap menunjukkan bahwa perbedaan rata-rata pertambahan berat badan harian dari masing-masing perlakuan. Po memperlihatkan berat badan rata-rata sebesar 86,7 gr/ekor/hari dan P1 memperlihatkan berat badan sebesar 132,65 gr/ekor/hari. Pengembangan agribisnis ternak domba dengan pemberian pakan suplemen berupa Bioplus dapat memberikan keuntungan yang layak sehingga dapat memberikan tambahan pendapatan bagi peternak.

\section{DAFTAR PUSTAKA}

Cahyono, B. 1998. Beternak Domba Dan Kambing. Kanisius. Yogyakarta.

Saragih, B. Suara Dari Bogor. Pustaka Wirausaha Muda. Bogor.

Undang-Undang Republik Indonesia No 16 2006. Sistem Penyuluhan Pertanian, Perikanan dan Kehutanan. Departemen Pertanian. Jakarta.

Slamet Margono, 2003. Membentuk Pola Perilaku Manusia Pembangunan. Institut Pertanian Bogor Press. Bogor.

Badan Pengembangan Sumberdaya Manusia Pertanian. 2005. Pedoman Penyelenggaraan Penyuluhan Pertanian Dalam Era Otonomi Daerah. Departemen Pertanian. Jakarta. 


\section{AIMBAR \\ Agribisnis}

ISSN 2460-432l

Volume 1・Nomor 2・Januari 2016

Purwanto. 2005. Programa Penyuluhan Pertanian. Sekolah Tinggi Penyuluhan Pertanian. Bogor.

Marzuki. 2001. Dasar-Dasar Penyuluhan Dan Modernisasi Pertanian. Bina Cipta. Bandung.

Ibrahim, Ahmad Sudiyono dan Harpowo. 2003. Komunikasi Dan Penyuluhan Pertanian. Bayumedia Publising. Magelang.

Departemen Pertanian. 2003. Pedoman Umum Pemilihan Metode Penyuluhan Pertanian. Badan Pengembangan Sumber Daya Manusia Pertanian. Departemen Pertanian. Jakarta.

Rahardi, F. dan R. Hartono. 2003. Agribisnis Peternakan. Penebar Swadaya. Jakarta.

Sodiq, A dan Zainal Abidin. 2002. Penggemukan Domba. Agromedia Pustaka. Jakarta.

Sarwono, B dan Arianto, H.B. 2002. Penggemukan Sapi Potong Secara Cepat. Penebar Swadaya. Jakarta. 